\title{
The Special Interest Tourism Development and the Small Regions
}

\author{
Drita Kruja* \\ Albana Gjyrezi** \\ Received: February 2011 | Accepted: May 2011
}

\begin{abstract}
It is easy to attract visitors when you have plenty of resources, nice accommodations, powerful selling techniques, many supporting sectors and of course reliable government support. The challenge starts when you lack most of the above and what you have is only a handful of beautiful natural resources, breathtaking sceneries, good will and a great desire and pride to show those visitors what your country is made of.

How can we generate income using what we have? The answer is simple. You target that group of customers whom are specifically interested in what you have, beautiful views, heartfelt welcome, home like accommodations and very warm people. These customers do not look for fancy, expensive, overcrowded hotels; they are in search of real beauty and nature. They have special interests and would like to fulfill them toward a reasonable price.

Hence starts the development of what is widely known as the special interest tourism whose analysis as a potential tool for the improvement of tourism in the region of Shkodra is the main purpose of this paper.
\end{abstract}

Keywords: special interest tourism, economic conditions, small regions, natural resources

\section{Introduction}

While we are all aware that Albania is blessed with a high diversity of resources and good opportunities for the development of tourism, we cannot say this sector is generating the expected results.

Rich natural resources, a breathtaking coastline, rich flora and fauna, historical, cultural and religious heritage, which all combined together within the same small country represent a big advantage for Albania.

* Faculty of Economy, University of Shkodra “Luigj Gurakuqi”, Albania, krujadrita@yahoo.com

** Freelance economic consultant, Virginia, USA 
Even though how much income do they generate? How many other sub-sectors does the development of tourism positively influence?

Albania was ranked in the 9oth place in the Travel and Tourism Competitiveness Index for the year 2009. Even though this is an improvement compared to 2008 Index where it was ranked $92^{\text {nd }}$, Albania is still far from its neighboring or similar size countries. Good examples would be Greece, Croatia, Montenegro, or even Macedonia, FYR ranked respectively $24^{\text {th }}, 32^{\text {nd }}, 52^{\text {nd }}$ and $80^{\text {th }}$ (Blanke, Chiesa, 2009).

These countries may not enjoy all the beauties and the resources that Albania has but for sure they implement the proper plans and developing strategies to reap the benefits of all their resources and generate considerable income from tourism.

In this context a question is raised: Will Albania be able to compete and gain a prestigious position in the tourism world market? Even though it may seem as a very ambitious goal it can be fulfilled. What is needed to achieve this goal? The answer would be easy: well developed infrastructure, star rated accommodations, clean environment, political stability and considerable investments. All of these should be combined under a detailed strategic plan. How much of this is controlled by the stakeholders of this sector? For sure not all of it. Can Albania build its tourist competitive advantage on the mass beach tourism, polluted waters and poor infrastructure?

The answer would be no. Competitive advantage comes as a combination of demand and innovation. It is created by offering the unusual, unseen, stunning but reachable product. This competitive product offers to the customers what they are looking for, what they want and what they are expecting to accomplish in their trips.

The purpose of this paper is to analyze special interest tourism as one of the most potential solutions for the development of tourism in Albania. It is organized in three parts.

The first part defines the special interest tourism and its main constituting categories which are adventure, rural tourism cultural, religious, ecotourism, culinary tourism and so on. It analysis the latest developments and trends of tourism sector. The methodology used in this paper is case study analysis. Three different case studies are presented and analyzed in the second part of the paper. They support the idea that development of special interest tourism can be effective and helpful for improving the economic conditions of regions regardless of size.

The first case study represents the development of new special interest tourism in the region of East Neuk, Scotland, UK. Development of special interest tour packages boosted the development of the tourism in the area. The second case study is on Thethi which is located in far North Albania and is very well known for its mountainous scenery, organic food, clean and fresh air, cool summers and very friendly people.

Sarda, on the other hand, which the third case study presented in this paper, is a small island in Shkoder. This island enjoys a rich religious heritage along with natural resources and because of its uniqueness can attract many visitors.

The third part provides the conclusions, suggestions and further research based on the analysis of the case studies presented. Following the positive outcomes of the first and second case study, we suggest that the development of special interest tourism would be a practical, if not the best solution to attract visitors, generate income and therefore create a sustainable economy.

It is important to note that this paper does not aim at making a distinction of what it is right or wrong for the development of tourism. It simply emphasizes that the development of special interest tourism can create benefits without the need of long term investments and solutions. 


\section{Special Interest Tourism - Definition and Trends}

A widely known and accepted definition of tourism is travel for leisure, business or recreational purposes.

In 1994 the United Nations defined three forms of tourism with regard to a specific country: (UN, 1994)

a) Domestic tourism;

b) Inbound tourism; and

c) Outbound tourism.

The first one involves residents of the same country traveling only within the same country; the second includes non-residents traveling into this country and the third one involves residents traveling in a foreign country. By combining these three basic definitions the United Nations created three main categories of tourism: internal tourism which is a combination of both domestic and inbound tourism, national tourism comprising domestic tourism and outbound tourism and international tourism which includes inbound and outbound tourism.

According to World Tourism Organization international tourism arrivals were 922 million in 2008 showing a I.9\% increase compared to the previous year (WTO, 2009). In the same year international tourism receipts were 944 billion USD (642 billion Euro), still showing a growth in real terms of I.8 \% compared to 2007 (WTO, 2009). In terms of country rankings, while France had the larger number of international tourist arrivals (79.3 million people), USA ranked first regarding international tourism receipts (IIO.I billion USD). German tourists were considered again for the fifth year in a row as the top international tourism spenders with (WTO, 2009). The most visited city for the year 2008 was London, UK with I5 million tourists (Bremner, 2OIO).

Despite these positive figures of 2008, the year 2009 showed a decrease in tourism numbers. According to WTO tourism international arrivals for this year were 880 million or $4 \%$ less than the previous year (WTO, 2OIO). Many factors and situations impacted this drop in tourism main ones being the global financial crisis and the HiNi outbreak. Nevertheless this decreasing tendency, some countries like China, Brazil and Spain experienced a notable growth in their domestic tourism, noted WTO (WTO, 2OIO).

During year 2OIO international tourism indicators will improve and the WTO has forecasted 3-4 \% increase during this year. On this regard UN-WTO Secretary General Taleb Rifai said: "Many countries were quick in reacting to the crisis and actively implemented measures to mitigate its impact and stimulate recovery. Although we expect growth to return in 2OIO, a premature withdrawal of these stimulus measures and the temptation to impose extra taxes may jeopardize the pace of rebound in tourism. As highlighted in the UNWTO Roadmap for Recovery, the sector can make a vital contribution to economic recovery, particularly as a primary vehicle for job creation and the transformation to the Green Economy. But to do so we need serious global policies that are supportive of tourism" (WTO, 2OIO).

Special interest tourism comprises different special interest travel forms which have become known as niche markets over the years and gained popularity among the actors of the tourism industry. While there is not a limit to these niche markets some of them have become more sustainable and considered categories of special interest tourism. These main categories along with a short description for some of them are:

a) Adventure tourism

b) Rural Tourism; 
c) Cultural tourism;

d) Religious tourism;

e) Ecotourism;

f) Culinary tourism;

g) Wildlife tourism;

h) Heritage tourism;

i) Medical tourism.

Adventure tourism: According to travel-industry-dictionary adventure tourism is "recreational travel undertaken to remote or exotic destinations for the purpose of exploration or engaging in a variety of rugged activities". Programs and activities with an implication of challenge, expeditions full of surprises, involving daring journeys and the unexpected. Climbing, caving, jeep safaris are examples of adventure tourism.

Rural Tourism: According to Eurostat (I998) rural tourism "regards the activities of a person travelling and staying in rural areas (without mass tourism) other than those of their usual environment for less than one consecutive year for leisure, business and other purposes (excluding the exercise of an activity remunerated from within the placed visited)".

Cultural Tourism: "Cultural tourism is a genre of special interest tourism based on the search for and participation in new and deep cultural experiences, whether aesthetic, intellectual, emotional, or psychological" (Stebbins,1996, p.948). This definition incorporates a variety of cultural forms, including the history, religion(s), art, architecture and other elements that have contributed in forming of the specific culture of the visited region.

Religious tourism: Is that form of tourism where groups of people or individuals travel for pilgrimage, leisure of missionary purposes.

Ecotourism: According to The International Ecotourism Society (I990) ecotourism is "responsible travel to natural areas that conserves the environment and improves the wellbeing of local people". While these definitions are helpful to support our idea and our choice of case studies, they would not be enough to understand special interest tourists. Instead we should focus especially on whom these tourists are, their characteristics and interests. Special interest tourists are generally adults or third age persons, adolescents and children (members of family or school groups), with the following characteristics:

- spirit of adventure;

- curiosity and

- sharing experiences.

Their intention is to travel to destinations which are environmentally and culturally rich, well conserved, seldom frequented and places where one can still enjoy the luxury of tranquility.

Special interest tourists enjoy activities in contact with nature, beauty of a conserved natural area, the pleasure of watching the fauna in its natural habitat, of exploring, discovering and learning, overcoming obstacles and feeling the pleasure of overcoming them. Furthermore they like to discover how easy it is to read a map, navigate a river and learn climbing techniques, diving, horse riding, canoeing, driving cattle, packing and carrying a rucksack. For that tourist the physical effort involved is a small price to pay for enjoying the view of a mountain, camping next to a lake of still clear water or watching an eagle soaring in the wind. Above all there is the pleasure of sharing experiences with friends and relatives. 
Albania has a lot of potential to satisfy this type of tourists. Albania has unique ecological features that provide significant but under-utilized tourism potential, including coastal areas, mountainous terrain, rivers, parks, and protected areas ( Kruja and Hasaj, 20IO, p.5). Its various resources can make it a unique destination among the neighboring countries. On the other hand, the international demand is present and increasing, so a lot of opportunities are there for Albanian tourism too. There are people, as mentioned above, who would be willing to pay hundreds of dollars for a tour package that satisfies their craving for adventure, nature exploration and admiration.

The Sector Strategy: Tourism Development in Albania, 20O2-2OI2 represents the three main segments of tourism market as following figure.

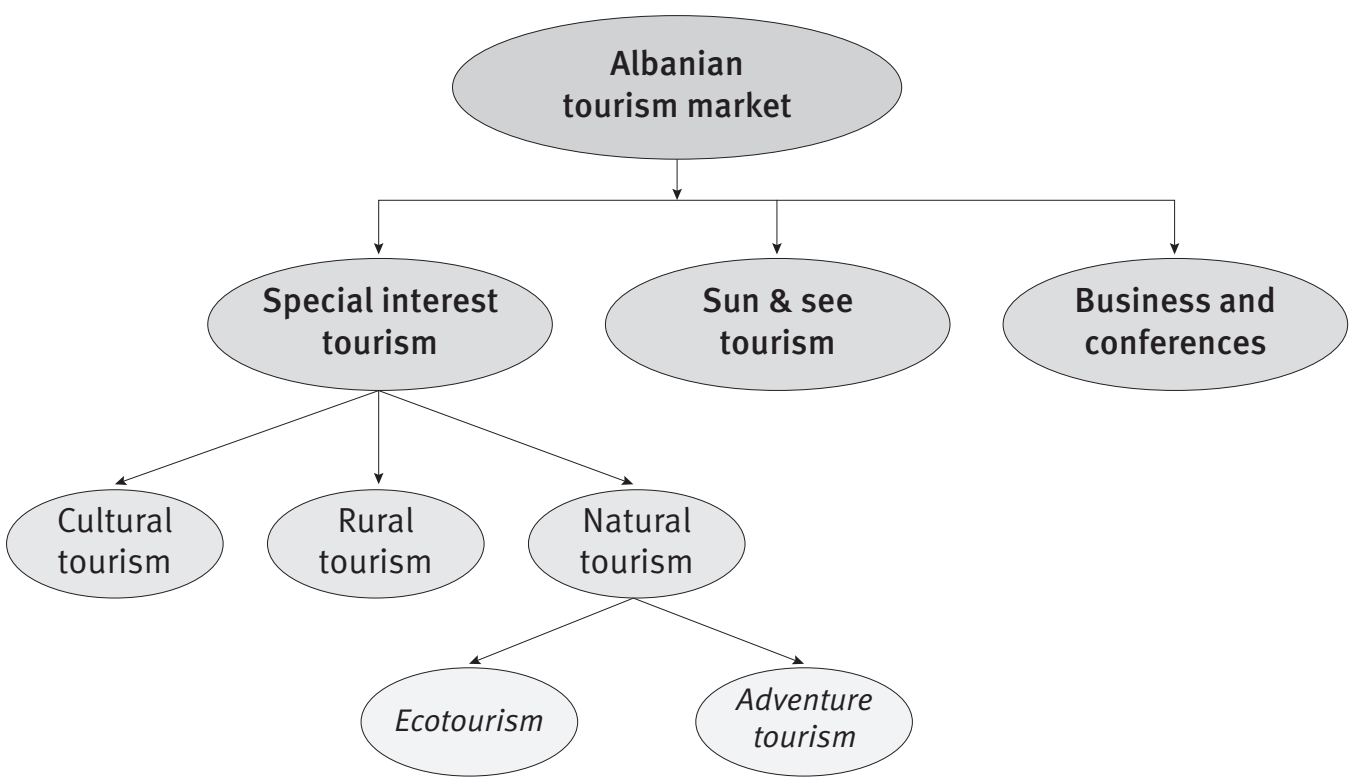

Figure 1 Main tourism products

Source: The Sector Strategy: Tourism Development in Albania, 2002-2012

Actually, special interest tourism is developed to a certain extent in Albania. There are only five tour operators who offer special interest tourism, mainly adventure tourism as their primary product. The majority of tour operators that offer special interest tourism services consider them as an extent to their primary product which is traveling outside Albania. The demand for the later has increased considerably during the last decade and it generates more income than other types of traveling. Also sun and beach tourism covers the majority of tourism market. But Albania definitely cannot compete Greece, Italy and other Mediterranean countries in this tourism segment (sun \& beach tourism for EU or other international tourists). Therefore one feasible option for the development of tourism would be special interest tourism. It has several advantages which can make it a good choice for tour operators. Some of these advantages would be:

a) Low start up investments compared to investments needed to develop mass sun and beach tourism;

b) The attractions, being those natural, religious or cultural do exist. The challenge is to find the right way to use and manage them; 
c) This type of tourism does not depend entirely on the development of infrastructure;

d) The demand for this type of tourism is growing;

e) Customers prefer more the tourism that offers new experiences and new unseen places.

The analysis of case studies which follows also support the main idea of this paper.

\section{Research Methodology}

The research methodology used in this paper is a combination of case study analysis and gathering of data to help this analysis. It has been chosen to ensure a better and deeper understanding of the development of tourism in a specific selected region. Since case study analysis is an ongoing process it helps identify both problems and solutions. Three different case studies have been chosen bringing three different perspectives, stages of development and results. While the case study of East Neuk can be considered successful, the one of Thethi on the good way of development, the case study of Sarda represents a potential which can be turn out to be successful if it follows the examples of the first two. Data has been gathered by using primary and secondary sources. As primary sources have served in depth interviews with tour operators, project managers, head or Sarda Association and officials of the Qarku Shkoder responsible for the managing of cultural resources of the Qarku Shkoder. Secondary data have been collected through studies and market analysis conducted by well known institutions as WTO, WTTC, GTZ and USAID.

\section{Case Studies}

\section{East Neuk, UK}

The first case study analyses the development of tourism in the area of East Neuk, UK. East Neuk is located in Scotland, only one hour far from Glasgow and the Scottissh Highlands. It is characterized by marine climate and is well known for its specialty food especially sea food. The area also has a long and rich nautical history and good tradition of artcrafts.

Nevertheless the tourism sector in the area was not very developed and businesses were not connected very much with each other. As a result this sector was not generating satisfactory income.

Considering the current situation which was not very satisfactory the Tourism Council of East Neuk decided to change the situation by bringing into play a marketing consulting company. The company analyzed the situation and suggested offering new touristic products and positioning them under an umbrella brand named "A Day in Neuk". Tracing of clans origins and other old cultural values was one of the new offered products. The target market for this product were tourists who stayed for a considerable amount of time either in Edinburgh or Glasgow. After analyzing this group of customers, it resulted that $65 \%$ of them came from either USA or Canada.

Another reason to consider this group was that $50 \%$ of tourists that came from USA or Canada wanted to discover their origins. As a result this new product offered by East Neuk

1 This case study was developed by consultants and tourism experts of EDEM/ USAID Project, Tirana, Albania 
was targeting the right market by offering to customers exactly what they were looking for. Seeing that this area had good culinary traditions, culinary tourism was developed as well along with cultural tourism.

As a result, in 2004 the income from tourism sector increased by IO\% compared to two years before.

\section{Thethi, Shkoder, Albania²}

Thethi is a village in the mountain area of the Albanian Alps, $78 \mathrm{~km}$ northeast of Shkoder. The northern mountain region is one of the poorest in Albania characterized by distressing depopulation due to remote location, lack of sources and isolation in wintertime ${ }^{3}$. While 500 people live in this village in summer, during winter this number shrinks to IOo. Traditional economic activity is agriculture. The geographic and climatic conditions allow only mountain meadows in summer and few garden products.

- Despite all this, Thethi and its surroundings have a high potential for tourism development. Some factors supporting tourism development would be:

- Very attractive alpine landscape. The highest top of the mountain peaks up to 2,659m above sea level ( Jezerca);

- Vast areas are declared National Park to preserve the ecosystem which has numerous rare species;

- The population saved their century- old traditions of rural life and hospitality.

- Considering all the above, in 2005 GTZ (The German Agency for Technical Cooperation) launched a project to develop tourism in Thethi. Before this project no form of tourism offer existed in the area. After the analysis of the situation in Thethi, numerous contacts with local families and responsible authorities the project was elaborated having as main objectives:

- Reduction of poverty through income generation in the tourism sector in a sustainable way;

- Reduction of emigration;

- Establishment of conditions for a market oriented and ecologically compatible tourism through development of modern types of specialty interest tourism as rural tourism, hiking, free climbing, biking, and so on;

- Improvement of the attractiveness of the cultural heritage like the historic houses, defense towers ( Kulla), mills and bridges;

- Upgrading of supporting infrastructure like medical facilities, renovation of the local school, and paving of the road Shkodra- Thethi;

- Increase the knowledge about the region and its tourism offer to attract more tourists.

Since the Project started quite a lot of positive changes have taken place. Several special tourism offers are implemented. Some of them are:

- Eight walking paths for hiking and trekking that existed in Thethi and nine more in the Albanian Alps are identified, marked and partly signposted. A detailed map and a

2 This case study was developed by consultants and tourism experts of GTZ project, Tirana, Albania and authors based depth interviews with the representatives of local government and local people

3 http://www.thethi-guide.com/ 
hiking guide are also available. The Thethi area offers a practical and attractive infrastructure for hiking and tracking tourists.

- For alpinists and free climbers several cliffs and routes are identified by experts. A small map is prepared.

- A bicycle tourism route from Shkodra to Podgorica through the mountain area of Northern Albania and Montenegro including Thethi and Plava is identified. This route is presented in a map prepared by Albanian and Montenegrin students of tourism branch supported by GTZ.

The efforts in the area of marketing for the Thethi lead to very good results. Therefore at the national level numerous articles and broadcasts have made Thethi in only two years one of the best known mountain destinations in Albania. The interest of Albanians to visit the destination is increased, local tour operators are more interested and have created tour packages for the destination, investors are looking for possibilities to invest and the administration and donors are more willing to support the development in the region.

At the international level, the efforts especially with the SR Broadcast created a lot of interest and requests for more information on the German speaking market.

The guidance from the Project and the efforts of the local families made possible that more than 5000 tourists visited Thethi in 2008. In the same year, IO families offered board and lodging in their historical stone houses and in two more modern houses 3I beds were available reaching a total of $\mathrm{I} 2 \mathrm{O}$ beds. The standard of the accommodation facilities was simple but sufficient to satisfy national and international target groups. Above all, the tourism spending in Thethi were estimated over IOO OOO EUR for the same year. For the families engaged in tourism activity this money was an important additional income. Some of them reinvested the profits for further improvement of their houses. One of the families is investing in building a hostel.

The initial skepticism among local people has quickly disappeared after realizing that having guests would bring more income for them. Family members have earned a lot of experience regarding guests' needs and wishes by having continuous contacts with them. These positive experiences and results encouraged other families to invest in tourism. Three new restaurants were open, an outdoor one by the river and two others near the church.

Three families invested in their houses to offer accommodation facilities following the standards of the GTZ project without financial support from the project.

Most of the other families in Thethi not yet involved in the project, try to participate in the tourism boom by offering overnight possibilities at a very low standard (without sanitary facilities, etc.).

This development shows that most of the families in Thethi recognize the growing demand as a chance to realize some income.

It is an important objective of the project to integrate these families in the project to ensure a certain quality in the area and secure a sustainable income for the families.

On the other hand, the competition among the families offering tourism facilities has started. Some problems with increasing prices and lower quality in some houses created a good counterbalance in competition. Most of the families are trying to increase their offer to better satisfy the guests.

After recognizing the success of the development of tourism in Thethi, the local administration and other donors have decided to cooperate in several ways to improve the infrastructure and tourism offer of the area. As a result: 
- During 2008, four out of nine pedestrian bridges were reconstructed with the support of UNDP (United Nations Development Programme) and Balkans Peace Park. Most of the existing bridges were in very bad conditions and not safe to use. They are very important for tourists and locals.

- Reconstruction of eight historical grind mills which are very interesting for tourism and important for the local population has started. Two mills are already reconstructed and in function. The mill close to the church and Kulla in Thethi has recently been completed and can now be used. The financing was realized by the Komuna Shale and MADA (the Mountain Association Development of Albania). The mills in Nderlysa were repaired by a project of UNDP.

- Hiking tracks have been marked with the support of UNDP.

- The Dutch Embassy in Tirana has financed the renovation of the tower "Kulla e Ngujimit"

- The German Embassy in Tirana has financed the renovation of the school building.

\section{Sarda, Shkoder, Albania ${ }^{4}$}

The ruins of the ancient town of Sarda are only $35 \mathrm{~km}$ far from Shkodra. In this area are also located the prehistoric habitation of Gajtan, the prehistoric habitation of Juban, the fortress of Dania and the fortress of Dalmaca.

Archeological data show that Sarda was founded around $6^{\text {th }}-8^{\text {th }}$ century BC and until the end of $5^{\text {th }}$ century it has been, a very developed and important center. The town also served as a crucial intersection in the old road connecting Gjakova with Shkoder and with Ulcinj. Sarda has been the residence of Dugjagjini family one of the most important Albanian feudal families

The artificial lake that surfaced as a result of the construction of hydropower plant of Vau i Dejes during the communist regime, turned Sarda into an island.

In this island visitors can see the ruins of the II $^{\text {th }}$ century medieval castle, which includes two rings of defensive walls and towers (some sadly submerged in the lake), the remains of a Byzantine church and other early medieval walls. The setting on the steep rocks rising from the lake is especially impressive.

The only way to get to this location is through the lake which by itself offers spectacular views.

When talking about Sarda as a tourist destination it is impossible to separate it from the artificial lake of Vau i Dejes and its picturesque shores. The creation of this lake has been and is a valuable opportunity for the development of tourism exceeding the damages it brought to the historical heritage of this area. With its clear and deep waters the lake offers a nice and very pleasant trip to the island. It is important to mention that the lake lies deep in the valleys and traveling with boat through it offers unique picturesque scenery. The later is an interesting combination of crystal clear blue waters, green vegetation, wildlife and limestone rocks which sometimes are craggy and sometimes not.

Even though the water of the lake has covered the surrounding wall of the castle of Sarda, the remaining walls and the church ruins are still very significant and fall easily into the eye of the visitor.

\footnotetext{
4 This case study was developed by authors based in depth interviews with tourism specialists in Qarku of Shkoder
} and the head of Sarda Association. 
The trip on the lake can start either from the dam of hydropower plant of Vau i Dejes which is also a nice view for the visitors or the dam of Rragami( a village in the region of Shkodra)

On the route to the island the visitors can see from the boat and learn about the Castle of Deja on which is located the Chapel of the Lady of Deja. This Chapel was built on the Mountain of Shen Marku by Scanderbeg after a victory against the Venetian Army in $5^{\text {th }}$ Century. After visiting the island of Sarda, the visitors can continue with a climb to the Cavern of Pellumbave on the north.

Sarda and its surroundings have great potential for the development of special interest tourism with activities like fishing, picnics or canoeing following different itineraries like Vau Deja-Lisna-Sarda- Cavern of Pellumbave and so on. These activities can be offered as tour packages to domestic and foreign tourists.

Nevertheless, the primary attraction of Sarda remains its ancient history and archeological heritage which needs to be discovered even further to add more value to the area.

\section{Conclusions}

Special interest tourism is one of the most interesting tourism sectors in Albania which has a great potential to successfully develop this type of tourism. It started slow but nowadays more and more tour operators and other tourism stakeholders are showing interest toward it. Investments in this sector are growing and resourceful but unknown locations are coming into existence.

"Bringing tourists into the yet-to-be discovered Albanian cultural landscape, where folk legends and history are combined into mystical scenery" (Mullai, 2005) has become a primary goal for the economic development of many regions in Albania. Thethi is one of them.

The tourism development in Thethi can be described as exceptionally successful. In less than three years the economic impact of tourism has grown from zero to highly considerable on the income of many families in the village. Tourism development is now seen as a realistic chance by the regional and national administration.

The quick increase of tourism offer and demand was only possible thanks to a wide and carefully structured approach followed by the GTZ project. This project covered all fields and topics important for tourism development from product development, marketing, distribution to supporting factors like infrastructure, local administration and so on.

Communities who are interested in developing tourism quite often will be sponsored by donor agencies or the government. However, experiences in all kinds of development work have shown that projects fully financed or run by donors fail at the moment the donor leaves the project.

The local community becomes used to the idea that money will just keep coming insomehow from somewhere-regardless of how well project performs commercially. Therefore it is important that local partners invest as well in the project. Examples would be constructing a guesthouse, improving the local landscape, keeping the environment clean, and so on. Their involvement is crucial not only for the success of the project but also for improving their economic conditions.

Potential tourism destinations, being those whole regions, single villages or small islands, which enjoy rich natural and cultural resources should rely on external expertise when the later is available either through donor projects, regional or national institutions. These sup- 
porting actors will help them make good use of their resources by starting to develop tourism.

As we mentioned above things have changed positively for Thethi due to awareness of the people responsible for the development of tourism, increase of awareness of its habitants and support of foreign donors.

Thethi is not a stand alone case. There are plenty of locations in Albania and we are sure in Kosovo as well that have the resources and the potential to return into popular tourism destinations. Even though it may be difficult at the beginning to bring visitors, advertise properly and generate considerable income on these locations; with the passing of time they will become steady as East Neuk did.

It is a well known fact that if the visitors will like the place when coming for the first time and will be satisfied they will come back and will spread the good word. Small changes and improvements in what already exists in these locations will make a big difference. The income generated will be reinvested, conditions will be improved and more visitors with come.

The development of special interest tourism does not require considerable investments. Small improvements in what already exists will make the difference. As tourism per se will develop other sectors that fuel it will "bloom" as well and its positive impact will be bigger.

\section{Recommendations}

The Tourism Development Strategy developed by the Ministry of Tourism, Youth and Sports of Albania forecasted that in two years from now, thus in 2012 the income from tourism would be 464 million USD. Was this goal too ambitious, too difficult or too easy? It is difficult to give a straight answer to this question. Goals cannot be difficult but sometimes the means to meet them can be. The purpose of this paper has been to identify special interest tourism as a mean for improving tourism development in Albania. Because of its characteristics which suit very well to the country resources it will attract more domestic and foreign tourists. We suggest that some of the ways to reach more foreign customers would be:

a) Promoting Albanian tourist attractions through Albanians who live and work outside the country.

b) Creation of a network of Albanian students who study abroad. They can promote special interest tourism to their classmates who can be interested to visit Albania. Even though students are a market segment with moderate income they can be a reachable target. They are in search of adventure and can be accommodated in simple and less expensive accommodation structures.

c) Combination of tour packages of international tour operators who already offer trips to other countries close to Albania. This way is easier for them to add Albania as part of their existing tour packages. Their customers can visit Montenegro for example and then travel to Albania and visit Thethi or Sarda. On the other hand it is easier and less expensive to realize such combination than have tourists travel by air to Tirana. International flights to Tirana are more expensive than similar flights to airports of neighboring countries.

d) Organization of familiarization trips. These trips combine tour operators from different countries who have common interests in a specific destination or type of tourism, for example special interest tourism in North Albania. The trip can be organized 
by a domestic tour agency, the regional tourism council, a donor project or any other tourism stakeholder. The group of foreign tour operators visits the tourism attractions, existing accommodations, restaurants and other supporting structures. If they find everything according to their specifications and that can meet their customers' expectations, then they can sign business contracts with the domestic partners.

Due to its structure and to fulfill its goal of analyzing real cases to support the idea of developing special interest tourism, this paper have not covered all the developing aspects of this sector. Therefore it leaves space for further research which we will continue by observing further on the development of tourism in Thethi and Sarda. We will also take into consideration another destination in the region of Shkodra, Zogaj a picturesque location by the lake of Shkoder. In the future research we would like to analyze the role of women in the development of family tourism.

\section{References}

Blanke, J. and Chiesa, T. (2009). The Travel and Tourism Competitiveness Report 2009. Geneva: World Economic Forum.

Bremner, C. (2OIO). Euromonitor International's Top City Destination Ranking. Euromonitor International.

Curiel, J. de E. and Gil, A. R. (2008). Religious Events as Special Interest Tourism. A Spanish Experience. Spain: PASOS. Revista de Turismo y Patrimonio Cultural, Vol.6. No. 3.

Eurostat (1998). Community Methodology on Tourism Statistics. European Commission. Luxembourg.

GTZ. Sector Strategy:Tourism Development in Albania, 2OO2-2OI2, November 2OOI

Kruja, D. and Hasaj, A. (2OIO). Comparisons of stakeholders' perception towards the sustainable tourism development and its impacts in Shkodra Region (Albania). Turizam. Vol. I4, Issue I, I-I2.

Mullai, N. (2005). Tourism Development - A catalyst for economic growth in Albania. Montreaux, Switzerland: Executive Forum on National Export Strategies,

United Nations Department for Economic and Social Information and Policy Analysis/ Statistical Division and World Tourism Organization (1994). Recommendations on Tourism Statistics, Statistical Papers, New York.

Stebbins, R. (I996). Cultural Tourism as Serious Leisure. Annals of Tourism Research, Vol. 23, 948-95O.

UNWTO (I998). Tourism 2O2O Vision-Europe, Madrid.

United Nations World Tourism Organization (2009). UNWTO World Tourism Barometer June 2009.

United Nations World Tourism Organization (2009). UNWTO Tourism Highlights 2009 Edition.

Internet Sources

http://www.ecotourism.org (visited for the last time on $04 / \mathrm{I} 5 / 2 \mathrm{OIO}$ )

http://www.wttc.org (visited for the last time on 04/I8/2OIO)

http://www.unwto.org (visited for the last time on $04 / \mathrm{I} 6 / 2 \mathrm{OIO}$ )

http://www.mtkrs.gov.al (visited for the last time on $04 / \mathrm{I} 8 / 2 \mathrm{OIO}$ )

http://data.un.org (visited for the last time on $04 / \mathrm{I} 6 / 2 \mathrm{OIO}$ ) 
http://www.albaniantourism.com (visited for the last time on $\mathrm{O} 4 / \mathrm{IO} / 2 \mathrm{OIO}$ )

http://www.travel-industry-dictionary.com/adventure-tourism.html (visited for the last time on $04 / 05 / 2010)$

http://www.thethi-guide.com/(visited for the last time on O4/I9/2OIO)

www.qarkushkoder.org/ (visited for the last time on O4/I9/2OIO)

http://www.gtz.de/ (visited for the last time on 04/09/2OIO) 